\title{
Correlation between the Holocene history of the Carpinus betulus and prehistoric settlement in North Poland
}

\author{
M. RALSKA-JASIEWICZ
}

\section{INTRODUCTION}

The influence of human cultivation upon the natural plant cover acquires an essential significance at the decline of the Holocene climatic optimum. From this time on the interpretation of pollen diagrams becomes difficult and is much more complicated by the increasing role of this additional factor which disturbs the picture of natural succession.

The problem of the Ulmus curve decrease which has been discussed for many years, is a good example. This decrease, appearing in the pollen diagrams from Western and Central Europe at the decline of the Atlantic period, is considered by some scientists to be above all the result of climatic changes but also of the activity of man (Iversen 1941, 1960); others, however, associate this fact mainly with the development of prehistoric settlement (Faegri 1944; Troels-Smith 1954, 1955).

The interpretation of the Sub-boreal breakdown of the Tilia curve presents similar difficulties. H. G o d w in $(1940,1960)$ explained its decrease by climatic revertence, according to the idea of von Post, and on these grounds drew in his stratigraphic scheme a line between the zones VII and VIII. Oldfield (1960, cit. after Turner 1962), admitted the possibility that man's activity had had an influence upon the course of the Tilia curves in the time under discussion. J. Turner (1962) confirmed this supposition taking as a basis an analysis of numerous diagrams. Moreover the dating of this author's material with the aid of radiocarbon proved that the Tilia decrease is not synchronous in the profiles and cannot therefore be a climatic phenomenon.

While investigating a profile from the Mikołajki lake, situated in the Masurian Lake District, the present author noticed some links between the course of the hornbeam curve and the procedure of the farming culture indicators, which were clearly visible in the pollen diagram (Fig. 1). 
TRACES OF HUMAN ACTIVITY IN A PROFILE FROM THE MIKOEAJKI LAKE

The first traces of the presence and activity of mani appear in the diagram from Mikołajki at the end of the climatic optimum (single pollen grains of Plantago lanceolata, Polygonum aviculare, Urtica) synchronously with the first distinct breakdown of the elm and ash curves. It seems probable that the decrease in the participation of these trees is connected with the settlement of the area, because after a short period of depression both the elm and the ash once more reach values not much lower than those they had before. This shows that the factor that brought about this phenomenon was not very intensive and comparatively shortlived. It could not then have been a climatic change of general significance.

In the second half of the Sub-boreal period there took place the next, this time definite breakdown in the elm curve and, somewhat later, also of those for the ash and the linden. The chief author of their decline was most probably man, as the increase in the curves of all synanthropic plants proves. At the same time the climate was changing into Sub-atlantic, which consequently gave rise to an expansion of new species of trees, especiaily of spruce and hornbeam. On the territories adjacent to Mikołajki the spruce has never played a more serious part; the hornbeam, on the other hand, soon became an essential element in the composition of forests. This territory lies within one of the two richest centres of the hornbeam in the Holocene of Central Europe ( $\mathrm{F}$ i r b a s 1949). This centre includes the middle and eastern part of North Poland. In some pollen diagrams from these territories the share of the hornbeam reaches in the Sub-atlantic period up to $40 \%$ (Dylewo) and $35 \%$ (Stążki). These are the highest values in the whole of Central Europe. Second rich centre of this tree, lying in northwest Germany the amount of its pollen rarely exceeds $20 \%$.

The Mikołajki lake is situated near the eastern limits of the Pomeranian centre of the bornbeam so that the share of this tree in the diagram is not great $(\max .8 .7 \%$ ).

The first culmination of the hornbeam curve is reached here towards the end of the Sub-boreal period. At the same time there appear vestiges of fire (small sized charcoal, sharp peaks of Pteridium and Polypodiaceae) as well as a great rise in the NAP curve and especially in that of the culture indicators (Artemisia, Rumex, Plantago lanceolata and P. maior). These are facts characteristic for the occupied areas. At the same time the Carpinus curve quickly falls, which permits the supposition that forests with hornbeam were particularly intensively destroyed.

In the first half of the Sub-atlantic period there appears a distinct breakdown in the curves for all synanthropic plants. Man had probably 


$$
\mid
$$


left the region of the Mikołajki lake and the first pioneer trees entered upon the abandoned grounds. This applied above all to the birch, by nature predestined to form transitory communities on places artificially deforested, especially on fire clearings (I versen 1941). In the diagram from Mikołajki the birch curve increases quickly almost from the beginning of the settlement phase but it reaches its highest values not earlier than towards the end of this phase and later, after the abandonment of the region by man. Beside the birch there also appears at this time the pollen of the genus Populus, probably P. tremula, a tree of a similarly pioneer character (P a c zoski 1930 ; I verse n 1949, 1960). Gradually forest of the original composition regenerates, this being well reflected by the hornbeam curve which reaches values even higher than before the interference of man.

A new surge of forest clearing produces in the diagram a combination of phenomena similar to the previous one and characteristic for the settlement phase. The culmination of the cultural indicators and the birch, synchronous with the breakdown in the hornbeam curve, proves that man again occupied the region of the lake, devastating the regenerated forest cover, especially the hornbeam forests.

In the middle part of the Sub-atlantic period there again follows a period of reduced husbandry, which allowed a partial regeneration of the original forest communities. Similarly as before, the forests with hornbeam are the first to regenerate, through transitory stages with birch and aspen. In the diagram the Carpinus curve culminates for the third time. A little higher, there appears the next, third in succession, settlement phase, which, this time, decreases the course of the hornbeam curve to a somewhat slighter extent. Pollen quantities of this tree appear now already in constant values, amounting to several per cent, up to the very peak of the profile.

\section{VARIATIONS IN THE HORNBEAM CURVES IN OTHER DIAGRAMS FROM NORTH POLAND}

The connection between the course of the hornbeam curve and the occurrence of synanthropic plants is clear in the diagram from Mikolajki and does not give rise to any doubt. The correlation is here somewhat different from that in the cases of the elm or linden quoted at the outset; after each destruction this tree obstinately regenerates. This is understandable if we consider that the hornbeam is at this time in the period of its main expansion in the Holocene. It is, moreover, characterized by great regenerative abilities, especially through stump shooting, which gave the tree chances of survival in difficult conditions. It can, for example, subsist in the form of small, barren shrubs on areas: periodically grazed down (cf. M i k k l lse n, 1953). 
Two or three breakdowns of the hornbeam curve appear also in other diagrams from the Masurian Lake District provided that its pollen values are sufficiently high (cf. papers by Gross; St a siak, 1961). H. Gross (1935) explains the first two depressions as being caused by factors of climatic character and associates only the third breakdown with forest clearing. This opinion has also been given by $\mathrm{F}$. Fir bas (1949). The diagrams of H. Gross are, however, lacking in pollen of herbaceous plants, the most important argument which would testify an anthropogenic origin of these breakdowns. Other phenomena connected with it (the culmination of the birch in the course of a hornbeam depression) appear in them clearly and regularly, which would seem to support such an interpretation. Thus it would appear that the conclusions concerning the Holocene history of the hornbeam, deduced from an analysis of the diagram from Mikołajki, apply also to other areas of the Masurian Lake District.

Why was it the hornbeam that suffered so much in consequence of the husbandry of the prehistoric settlers? The answer that suggests itself is simple. On poor, sandy soils there prevail today mixed (mainly Pino-Quercetum) and on more fertile soils oak-hornbeam forest (Querco-Carpinetum) (cf. F a liński, MS). Naturally we do not know how long ago these associations developed into their present form. It is, however, highly probable that the history of oak-hornbeam communities, reaches back to the beginning of the Sub-atlantic period. Already then the hornbeam was incident to forests growing on fertile soils which were eagerly exploited by man for the purpose of cultivation as well as for pasture. It is also understandable that these communities, corresponding to the present Querco-Carpinetum associations, were those most devastated during periods of intensive settlement (cf. Kornaś, 1959; Srodon 1959). If the oak was already at that time the second tree beside the hornbeam, that formed forests on good soil, it might be expected that its curve would show similar depressions; this, however, is missing in the examined diagrams. The reasons may be various. Firstly, man, with his primitive methods of forests clearing, probably destroyed only the smaller trees and shrubs, leaving the large and single growing oaks that did not particularly impede him (I versen 1941). Secondly, even if the number of oaks were reduced by the cutting down of large areas of forest, then this could be remedied by a flight of oak pollen from adjacent territories with sandy soils covered by pine-oak forest.

The devastation by the prehistoric settlers of forests abounding in hornbeam did not only take place in the Masurian Lake District. This is being proved by, changes, similar to those described above in pollen diagrams deriving from other regions of North Poland. In Fig. 2. details from several diagrams that illustrate the discussed problem are assem- 
bled. Besides the hornbeam curve the birch curve has been used, since it is the most characteristic tree for the secondary, post-settlement communities (calculated on the grounds of $\mathrm{AP}=100 \%$ ). As for herbaceous plants the summary curve for the synanthropic indicators and a laid on curve for Gramineae (both calculated in relation to $100 \%$ AP and twice scaled up) have been used. The common leading level in Fig. 2. is the first culmination of the hornbeam.

In a diagram from Stążki, situated in the Kartuzy Lake District ( $\mathrm{Szafrank \textrm {i }}$ 1961), the values for the hornbeam are very high (up to $35 \%$ ) and the depressions sudden. Two settlement phases of the territory can be distinguished, both having a regular and mutually very similar course. Simultaneously with a sharp breakdown in the hornbeam curve there occurs a rise in the culture indicators and immediately afterwards a culmination of the birch. After the second phase there follows a longer period of reduced human activity when the hornbeam regenerates abundantly, reaching the highest of the Holocene values. Its curve again falls only in historical times; this, however, has not been taken into consideration in fig. 2 .

In a diagram from Mielno, situated in the area of Dobrzyn (K ę pc zynski 1960), the first and the third settlement phase are strongly marked whereas the middle one is not very distinct; the birch and the synanthropic plants maintain fairly high values while the hornbeam curve rises comparatively little. Probably man was living somewhere in the vicinity all the time.

In a diagram from Źuchowo, also situated in the area of Dobrzyn (O s z a st 1957), after a transitory, short-lived breakdown in the hornbeam curve, which finds only a faint reflection in the course of the birch curve, there follows a long settlement phase leading to an almost complete extermination of that tree. It regenerates once more, however, taking advantage of a period of reduced settlement only to succumb finally to its next wave.

The remaining diagrams show the results of investigations carried out by H. Gross $(1935,1936)$, from the territory of Masuria and Warmia compared with the profile from Mikołajki. The first one derives from the Primeval Forest of Dylewo near Lubawa, the second from Braniewo near Frombork, and the third from Szczecinowo near Ełk. None of these diagrams include any curves for herbaceous plants but they illustrate well the conformity of behaviour of the hornbeam and the birch in the whole of this territory.

The material quoted here shows that the selective devastation of hornbeam forests was a phenomenon of rather general character during peak periods of prehistoric settlement. Such a result of investigations contradicts the opinion that in the Sub-atlantic period human activity favoured 
the hornbeam, because felling and clearing of forests created advantageous conditions for its regeneration (I. M üller 1947; D ą browski 1959). F i r b a s (1949), while acknowledging that such an interpretation is possible, states at the same time that in the north-west German centre of the hornbeam there are no proofs whatever to support this hypothesis. On the contrary, K. S t e in berg (1949), proved for the south-western submontane areas of the Harz that the culmination of the Carpinus falls just between two maxima of cereals, at the time when their pollen grains in the diagram are not numerous or vanish completely (cf. also Kubitzki 1961). H. Müller (1953), in his profiles deriving from steppe areas situated on the lower Saale, distinguishes several phases of intensive human husbandry separated by periods of forest regeneration. This author maintains that in the Sub-atlantic period, when the hornbeam was attaining its maximum values in this region, forest clearing took place mainly at the expense of forests rich in this tree.

Also in W. Mikkelsen's (1954) diagram from Bornholm which represents forests with a large share of hornbeam, there appears a sudden breakdown in its curve in the middle part of the Sub-atlantic period. W. M i k k elsen $(1954,1963)$ explains this depression, synchronous with a culmination of Betula, Gramineae, and the Ericaceae, by the fact that large scale forest clearing took place in order to obtain pasture land.

It seems that the history of the hornbeam in the Holccene on the territory of Central Europe is strictly connected with human activity. This species was particularly devastated in periods of intensive settlement on account of the fertility of the occupied habitats. The fact that this tree was able to survive down to the present day as one of the main components forming oak-hornbeam forests, must be ascribed to its ability to regenerate in a comparatively short time and to its great spread over certain territories.

Botanical Institute of the Polish Academy of Sciences, Paleobotanical Laboratory

(Entered: 18.XI.1963)

\section{REFERENCES}

D ą b r o w ski M., 1959, Późnoglacjalna i holoceńska historia lasów Puszczy Białowieskiej, Acta Soc. Bot. Pol. 28:197-248.

F a e gri K., 1944, On the Introduction of Agriculture in Western Norway, Geol. Fören. Förh. 66:449-462.

F a liński J. (rękopis), Zbiorowiska łęgowe Krainy Wielkich Jezior Mazurskich. Firbas F., 1949, Spät- und nacheiszeitliche Waldgeschichte Mitteleuropas nördlich der Alpen, Bd. 1:480 pp, 2:256 pp., Jena, G. Fischer.

Godwin H., 1940, Pollen Analysis and Forest History of England and Wales, New Phyt. 39:370—400. 
Godwin H., 1960, Radiocarbon Dating and Quaternary History in Britain, Proc. Roy. Soc. B 153:287--320.

Gross H., 1935, Der Döhlauer Wald in Ostpreussen, Beih. zum Bot. Centralbl. 53/B:405-431.

Gross H., 1936, Die Steppenheidetheorie und die vorgeschichtliche Besiedlung Ostpreussens, Altpreuss. 4:193-216.

Kępczyński K., 1960, Zespoły roślinne Jezior Skępskich i otaczających je łąk, Stud. Soc. Scient. Tor. Suppl. VI:1-244.

Kondracki J., 1957, Pojezierze Mazurskie jako region naturalny, Geogr. w szkole $5: 1-16$.

Kornaś J., 1959, Wpływ człowieka i jego gospodarki na szatę roślinną Polski Flora synantropijna. Szata roślinna Polski, T. 1:89-125.

Kubitzki K., 1961, Zur Synchronisierung der nordwesteuropäischen Pollendiagramme (mit Beitrage zur Waldgeschichte Nordwestdeutschlands), Flora 150: $43-72$.

I versen J., 1941, Landoccupation in Denmark's Stone Age, Danm. Geol. Unders. $2(66): 1-68$.

Iversen J., 1949, The Influence of Prehistoric Man on Vegetation, Danm. Geol. Unders. 4(3):1-25.

I versen J., 1960, Problems of Early Post-Glacial Forest Development in Denmark, Danm. Geol. Unders. 4(4):1-32.

Mikkelsen V., 1954, Studies on the Sub-atlantic History of Bornholm's Vegetation, Danm. Geol. Unders. 2(80):210-229.

Mikkelsen V., 1963, Beech as a Natural Forest Tree in Bornholm, Bot. Tidsskr. 58(4):253-280.

M ü11 e r H., 1953, Zur spät- und nacheiszetlichen Vegetationsgeschichte des mitteldeutschen Trockengebietes, Nova Acta Leopold. 16(110):1-67.

M üller I., 1947, Der pollenanalytische Nachweis der menschliche Besiedlung im Federsee- und Bodenseegebiet, Planta 35:70-87.

Oszast J., 1957, Historia klimatu i flory Ziemi Dobrzyńskiej w późnym glacjale i holocenie, Inst. Geol. Biul. 118:179-232.

P a c zoski J., 1930, Lasy Białowieży, 575 pp., Poznań, Państw. Rada Ochr. Przyr. St a siak J., 1961, Pieczonki - Profile of Lacustrine Sediments; Alleröd, Younger Dryas and Holocene, VIth INQUA Congress Publications, Guide-Book of Excursion D:54-56.

Steinberg K., 1944, Zur spät- und nacheiszeitlichen Vegetationsgeschichte des Untereichsfeldes, Hercynia 3(7/8):529-587.

Szafrański F., 1961, Polodowcowa historia lasów obszaru na północ od Wysoczyzny Staniszewskiej (Pojezierze Kartuzkie), Bad. Fizj. nad Polską Zach. 8:91-136.

Ś rodoń A., 1959, Zarys historycznego rozwoju szaty roślinnej Polski w późnym glacjale i holocenie, Szata roślinna Polski 1:513-543.

Troels-Sm ith J., 1954, Erteböllekultur - Bondekultur, Aarbøg. for Nord. Oldkyn. og Hist. 1953:1-62.

Troeis-Smith J., 1955, Pollenanalytische Untersuchungen zu einigen Schweizerischen Pfalbauproblemen, Das Pfalbauprobl. Mon. zur Urund Frühgesch. d. Schweiz. 11:11-64.

Troels-S mith J., 1960, Ivy, Mistletoe and Elm Climate Indicators-Fodder Plants, Danm. Geol. Unders. 4/4:1-32.

Turner J., 1962, The Tilia decline: an Anthropogenic Interpretation, New Phyt. $61(3): 328-341$. 


\section{Zwiazek między historia graba a fazami zasiedlania przez człowieka terenów pótnocnej Polski}

\section{Streszczenie}

W diagramie pyłkowym z osadów dennych Jeziora Mikołajskiego (Pojezierze Mazurskie) zwraca uwagę wyraźny związek pomiędzy przebiegiem krzywej graba a zachowaniem wskaźników kultur ludzkich (ryc. 1).

Krzywa graba wykazuje tutaj trzy wyraźne depresje: przy końcu okresu subborealnego oraz w środkowej i w młodszej części okresu subatlantyckiego. Są one synchroniczne z trzema wyróżnionymi w diagramie fazami zasiedlenia terenu przez człowieka, które charakteryzują się kulminacją roślin zielnych, a zwłaszcza wskaźników synantropijnych: Artemisia, Rumex, Plantago lanceolata i Cerealia oraz brzozy. Powtarzająca się równoczesność tych zjawisk pozwala przypuszczać, że w okresach nasilenia gospodarki lasy grabowe były niszczone intensywniej aniżeli inne zbiorowiska leśne. Pomiędzy fazami zasiedlenia występowały okresy osłabienia działalności człowieka, w czasie których na porzuconych przez osadników terenach rozwijały się najpierw przejściowe zbiorowiska drzew pionierskich, głównie brzozy, a także i osiki, następnie odnawiały się lasy z grabem.

Załamania krzywej graba synchroniczne z kulminacjami wskaźników kulturowych i brzozy występują i w innych diagramach z Polski północnej, będącej jednym z ośrodków obfitego występowania tego drzewa w holocenie Europy środkowej (O s zast 1957, K ęp czyński 1960, Szaf r a ń s k i 1961). Zjawisko to można prześledzić także w niektórych dawniej opracowanych diagramach pyłkowych z Pojezierza Mazurskiego $i$ to pomimo braku w ich składzie roślin zielnych (Gross 1935, 1936). W diagramach tych podczas depresji graba występują regularnie kulminacje brzozy, co skłania do przyjęcia ich antropogenicznej interpretacji.

Analogiczne zmiany stwierdzono w diagramach pyłkowych z północno-zachodnich Niemiec (Steinberg 1944, Müller 1953, Kubitzki 1961) i Bornholmu (M ikkelsen 1954, 1963). Wybiórcze niszczenie lasów obfitujących w graba w okresach intensywnej gospodarki było więc zjawiskiem ogólniejszej natury. Żyzne gleby, na których te lasy występowały, były prawdopodobnie najchętniej wykorzystywane przez osadników i to zarówno w celach uprawy, jak i na pastwiska. Wydaje się przeto, że jedynie dzięki dużej ekspansywności oraz zdolnościom do szybkiego odnawiania grab zdołał zachować swe znaczenie w składzie lasów wspólczesnych. 